Working

Paper

Department

of Economics

$\mathrm{Ca}^{\prime}$ Foscari University of Venice

Ignazio Musu

Intellectual Property Rights and Biotechnology:

How to improve the present patent system 


\title{
Intellectual Property Rights and Biotechnology: How to improve the present patent system.
}

\author{
Ignazio Musu \\ Ca' Foscari University of Venice
}

\begin{abstract}
The paper discusses two types of problems related to assigning or denying intellectual property rights to agro-biotechnological innovations in the relation between developed and developing countries. First, protecting property rights on innovations creates incentives towards further research and innovation, which in some cases may be beneficial to society, in others not so. If the assigning of the right does not guarantee the potential beneficial use of the innovation, not assigning rights would not prevent its potentially dangerous utilization. Secondly, the power of exclusion of the holder of an intellectual property right limits access to the newly produced knowledge: this may discourage the process of producing new knowledge, harming developing countries. Moreover the property right holder may end up with excessive market power when commercializing the innovation, which is also harmful to developing countries. It is shown that these problems cannot be solved by denying protection to property rights on innovations, but by improving procedures for awarding these rights and accompanying them with appropriate liability rules and antitrust measures.
\end{abstract}

Keywords: Intellectual property rights, Biotechnology, Patent system

JEL Codes: O30, O33, O34

\author{
Address for correspondence: \\ Ignazio Musu \\ Department of Economics \\ Ca' Foscari University of Venice \\ Cannaregio 873, Fondamenta S.Giobbe \\ 30121 Venezia - Italy \\ Phone: (++39) 0412349151 \\ Fax: (++39) 0412349176 \\ e-mail: musu@unive.it
}

This Working Paper is published under the auspices of the Department of Economics of the Ca' Foscari University of Venice. Opinions expressed herein are those of the authors and not those of the Department. The Working Paper series is designed to divulge preliminary or incomplete work, circulated to favour discussion and comments. Citation of this paper should consider its provisional character.

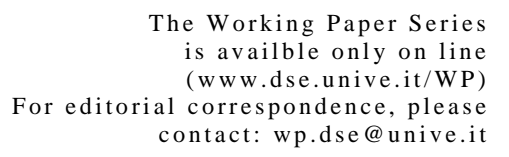

he Working Paper Series is availble only on line contact:wp.dse@unive.it

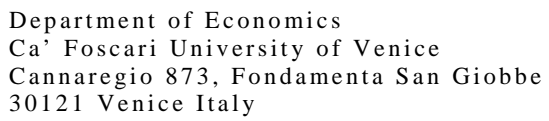

Department of Economics

Ca' Foscari University of Venice

Cannaregio 873, Fondamenta San Giobbe

30121 Venice Italy

Fax: ++390412349210 


\section{Introduction}

Traditionally, intellectual property rights have been considered to be the "natural" right of the inventor, to be protected in order to prevent others stealing the fruits of the inventor's research efforts. This vision is often countered by an opposing one, which considers it inappropriate to assign private property rights to intellectual creations, since, the argument goes, knowledge is a public good which should be freely available to everybody for the well-being of human society as a whole.

Recently, protection of intellectual property rights on new knowledge has been advocated as the best means to promote technological progress. The starting point of the argument is that once knowledge has been produced, it can be utilized by everybody at a very low marginal cost. If we consider that the costs of obtaining existing knowledge are "sunk", and acceding to new knowledge entails paying a price equal to the marginal cost of knowledge utilization, this price would not adequately reward the costs of producing new knowledge in the future. Knowing that any future research efforts would not guarantee appropriate returns will undoubtedly discourage such efforts.

Price incentives are not the only type that encourage efforts to obtain new knowledge: there are others, such as personal satisfaction, the vocational calling to research, social recognition through reward, recognition and academic career advancement. But price incentives are important, and they can be provided by awarding rights to the intellectual property of new knowledge.

Assigning a property right to a producer of new knowledge excludes others from utilizing it unless they obtain a license from the right holder, obviously at a price. This price must be higher than the marginal cost of utilizing the 
produced knowledge and high enough to be perceived as an incentive to produce new knowledge (Maskus, 2000; Posner and Landes, 2003).

Basically, there are two types of problems to consider. First, the aim of protecting property rights on innovations is to create incentives towards research and innovation in general; the risk is that this may give vent to socially dangerous innovations. However, in most cases it is not easy to establish whether or not an innovation is beneficial or dangerous, especially because it may be subsequently utilized in many ways, some of which may be beneficial to society, others not so. In this case, if the assignment of an intellectual property right does not guarantee the potential beneficial use of new knowledge, not assigning rights would not prevent its potentially dangerous utilization.

Secondly, the holder of an intellectual property right has a power of exclusion which limits access by others to the newly produced knowledge. However, the production of new knowledge is very often a process which starts from a base of existing knowledge. Hence, discouraging access to existing knowledge also means discouraging the process of producing new knowledge. Paradoxically then, in protecting intellectual property we obtain the opposite result to the one expected and desired. Moreover, the holder of an intellectual property right may end up with excessive market power when commercializing the innovation.

Applied to biotechnological innovations, these two types of problems emerge in all their complexity, involving in particular relations between developed and developing countries. They will be discussed in the following sections, with particular reference to agro-biotechnologies. I will try to show that these problems cannot be solved, as sometimes is suggested, by denying protection of property rights on innovations, but by improving the procedures for awarding these rights and accompanying them with other 
measures such as liability rules governing potential damage and also antitrust measures.

\section{Social costs and benefits of biotechnologies, and protection of intellectual property rights.}

Nobody doubts that biotechnology is currently one of the most important expressions of technological progress. As is well known, it embraces all technologies that use molecular and cellular biology for solving problems linked to agriculture and food, as well as human health. Medical biotechnology has applications both in diagnosis and in producing new drugs. Biotechnologies applied to agriculture are used for producing and modifying plants, animals and micro-organisms. Plants and animals have been modified for the benefit of humankind for hundreds of years using conventional methods, such as grafting and selective breeding; biotechnology has now introduced an unprecedented qualitative change by enabling human beings to transfer genes from one species to another.

A debate is developing on the social benefits and costs of biotechnologies, with extreme opposite positions emerging: on the one hand, unconditional optimists maintain the widespread belief that technological progress in biotechnologies is always good and should be given free rein to develop; on the other hand, unconditional pessimists consider any biotechnological innovation dangerous simply because it is the result of unnatural human intervention in natural life processes.

These extreme positions are rooted in the premise that general brad-ranging propositions will be valid for any type of biotechnological innovation. This is simply not the case because the social benefits of some biotechnologies are likely to be greater than their social costs; for others, the opposite is likely to be the case. This is something not always easy to establish due to the high level of uncertainty resulting from a lack of scientific knowledge 
and the fact that most effects of the innovations will only become apparent in a distant future. What should be done is to improve scientific knowledge by helping to better understand the effects of innovations and to use institutional channels to encourage those innovations which promise to be more beneficial and less risky to society.

The most commonly recognized benefits of biotechnological innovations are in resource productivity, considered both in terms of higher output per unit of primary resources and in a higher variety of outputs. In the case of medical biotechnologies, the most important benefits concern the second point: for instance, production of proteins for curing and preventing diseases, and therapeutic applications of research using in vitro cultivation of stem cells. In the case of agricultural biotechnologies, the most important benefits concern both aspects: increase in crops' yields through better plant resistance to adverse factors, and the possibility of producing new plant varieties.

The risks and costs of biotechnologies concern their effects on the environment and consequently on human health. Consider as an example herbicide-resistant GM plants. Herbicides contained in plants directly and indirectly enter the food chain, and can damage human health. Water sources are also polluted when herbicides are discharged into them. Reducing the first type of negative effects, herbicide-resistant GM plants appears to be beneficial to society. But the introduction of such an innovation is unlikely to reduce the use of herbicides; on the contrary, farmers are likely to use more herbicides to destroy weeds, as they are less concerned about the damage produced in the plants they grow.

Moreover, herbicide-resistant genes can cross over to other plants, including the weeds that should be destroyed; the risk here is that the creation of "superweeds" would entail searching for more powerful and possibly more risky herbicides. GM plants could themselves begin behaving like weeds if 
their new, superior genetic characteristics give them a comparative advantage over neighboring wild species (Dutfield, 2004, p.63).

Pest-resistant GM plants are another example of agro-biotechnological innovation. They should lead to a reduction in the use of pesticides. However, attention should be given to nature's reaction to neutralize human intervention by selecting the most resistant elements in the population concerned (Goeschel and Swanson, 2002, 2003, 2004). The defensive reaction of pests could lead to the emergence of "super-pests", the development of which is likely to encourage the invention of new GM plants resistant to the new types of "super-pests" or, if research is unable to find them, more powerful and potentially dangerous pesticides may be used.

An important and much-debated effect of biotechnologies on the environment is on biodiversity. Biodiversity refers to the variety of biological species in a given ecosystem, necessary for its functioning. It is eventually determined by the stock of genetic material found in the ecosystem itself. Biodiversity should be preserved because of its information value and because of its insurance value (Swanson, 1997). Biodiversity is the result of the whole history of evolution, and offers an irreplaceable corpus of information on the possible directions which biological activity might take. This information must be screened in order to be utilized. Scientific research is essential, but the screening process can also be improved by using "traditional knowledge" gathered by human communities in their interaction with the environment. Biodiversity also has an insurance value, because it ensures smoother adjustment to the negative shocks suffered by an ecosystem. In biological terms, we might say that a highly diversified ecological system increases its resilience to shocks; in economic terms, we can say that a rich portfolio of biological activities reduces the variability of their returns and the risk implicit to the biological structure. 
Some believe that biotechnological innovations are a threat to the maintenance of biodiversity, since they represent a typical form of technological progress that substitutes natural capital with artificial capital, leading to an increase in biological specialization. Others, on the contrary, believe that biotechnology can help maintain and possibly increase biodiversity since, through biotechnology, it is possible to transfer successful biological strategies between species and thus to obviate the erosion of genetic stock that may result from biological specialization.

The obvious question now is the following: how can society ensure that the protection of intellectual property rights, by promoting innovations unconditionally, does not lead to the introduction of excessively risky and socially dangerous biotechnological innovations?

The most frequently used mode of protection for intellectual property rights on innovations are patents. In principle, it is possible to prevent patenting socially dangerous innovations. This provision is made clear in the Trade Related International Property System Agreement (TRIPS agreement), incorporated into the World Trade Organization agreements. According to article 27.3b, inventions contrary to public order or to ethics, or dangerous for the health of humans, the life of animals and plants, or environmentally dangerous, can be denied patents. However art. 27.3b specifies that countries cannot deny patents for microbiological processes, and this amounts in practice to excluding a selective patentability for biotechnological innovations. No surprise that this specification has been strongly criticized by those opposed to awarding patents to biotechnological innovations (Shiva, 2001).

Opponents of patenting biotechnological innovations invoke the precautionary principle. Their argument is that when there is any uncertainty regarding the effects of the innovation on the environment and on health, the innovation should be blocked, until research and science provide more 
information. This is precisely the case with biotechnological innovations. The problem with the precautionary principle lies in interpreting the requirement that uncertain effects should be absent. There is the risk that if the precautionary principle is always invoked, there will be no innovation at all. To prevent this from happening, a probabilistic formulation of the principle should be adopted, requiring that the probability of negative effects is shown to be sufficiently low.

A recent example of a wise application of the precautionary principle is the Cartagena Protocol on biological safety required by article 19.3 of the Biodiversity Convention. In articles 10 and 11, the Cartagena Protocol explicitly refers to the principle of precaution, as the basis on which a country should adopt restrictive measures against LMO imports, whenever there is insufficient scientific information on the product's potentially hazardous effects. Although this example does not refer to patentability, it is useful as a constructive application of the precautionary principle, as it suggests that, before taking trade restrictive measures, every effort should be made to identify and appropriately assess the potential risks and decide whether or not any restrictions ought to be placed on developing the product. It should be noted that no contradiction exists with the WTO agreements, as GATT article $\mathrm{XX}$ envisages that certain measures are justified when necessary, in order to protect the life and health of humans, animals and plants, and to preserve natural resources.

An important aspect to be considered is that awarding a patent does not automatically and unconditionally imply the right to transform an innovation into a product or a commercial process. Commercial potential is a condition for awarding a patent, but that does not mean that commercial use is automatically permitted. This will depend on legislation and will reflect a society's ethical values in determining the conditions for a socially efficient commercial application of a patented innovation (Di Cataldo, 2003). 
Moreover, it is important to realize that negative effects are not necessarily avoided by prohibiting patents, as this does not imply that an innovation will not be introduced and marketed. Without an explicit and enforceable prohibition to the introduction and diffusion of a product, biotechnological innovations, as any innovation, can be developed and introduced without patents. In doing so, potential negative effects are often concealed. Thus, paradoxically, if an invention is introduced and diffused without a patent being first awarded, the risk for human health and the environment can be higher.

Rather than adopting a general strategy of denying patents a priori, it seems more useful to qualify the procedure for awarding them and to accompany patents with other measures. Alterations to patenting procedures should aim to carefully specify the characteristics of the product or process to be patented, and to take account of its potential effects on the biological world, on the environment and on human health.

Patents as a tool for stimulating innovations should be accompanied by efficient liability systems. Knowing that someone who introduces a hazardous innovation will be held liable for any related damage, particularly if knowledge about this damage was concealed, is a clear disincentive for not revealing all the potential known consequences.

\section{Intellectual property rights on biotechnologies and excessive exclusion power: a tragedy of anti-commons.}

Protection of the intellectual property rights on an innovation always assigns a power of exclusion. There are two consequences to consider: one concerns the use of the innovation for further research; the other is the restrictions in the use of the innovation for commercial purposes. In the first case, the 
excessive power of exclusion assigned to a right holder may prevent rather than promote the production of new knowledge, giving rise to a "tragedy of anti-commons" (Heller, 1998; Colangelo, 2004) as opposed to the "tragedy of commons” which occurs when there is open and free access to produced knowledge, leading to a lack of incentives to undertake efforts to create new knowledge.

The problem cannot be solved by denying patentability, but should rather be addressed by altering rules for procedures. Consider the example of decoding genes or gene sequences. An objection against patentability is that decoding is not an invention, but a discovery of something existing in nature. This objection does not convince because the novelty in this case lies not in what has been discovered, but in the fact that this is being presented in such a way that makes further utilization possible.

Another aspect of patentability should be mentioned. If patenting decoding means assigning the patent holder an exclusion right on any possible use of the decoded gene or sequence, the risk of preventing the development of further research is evident. The excessive exclusion power derives from the fact that decoding by itself cannot be immediately associated with a specific function; it will have many different potential uses. This is why the US Patent Office only grants patents of decoded sequences if applications specify which protein the sequences codify, or in the case of virus genome decoding, if patent applications specify the function of diagnosing a specific illness and therefore of finding a suitable vaccine. In other words, patenting covers the discovery only in relation to a specific application that must be indicated. This means that the owner of the patent can use property rights towards others wanting to use the gene or sequence, only for the specific use described in the patent application. Notice that in this way the patenting procedure can also ensure that patents do not create conditions for excessively risky and socially dangerous innovations. 
Consider now the first stage of the production process of genetic material, such as genes or DNA sequences reproduced and proteins encoded from sequences using genetic engineering techniques i.e. DNA recombining techniques. In this case too, the objection raised against patentability is that the process obtains something already existing in nature. This objection can be countered by using the former argument; moreover, the example can be cited of the recognized patentability of chemical substances existing in nature and obtained through synthetic processes.

In this case, exclusion power also allows the patent holder of the technique to extend the patent's right to all the products obtained through that technique. This clearly discourages further research. The solution, even in this case, is not to deny granting a patent for the technique, but to acknowledge the right to patenting different products obtained with that same technique, and recognizing the novelty of the intellectual process which uses the technique to obtain the new product. Likewise, the patent holder of a new product should not have a right of exclusion towards innovations that obtain the same product through different techniques.

Moreover, to ensure that research is not negatively affected, the holder of a patent on decoding a genetic sequence or on a biotechnology for producing a genetic product should not have the right to prevent the use of the gene in its natural form for further applications (Correa, 2000, p.181).

To avoid a scenario in which patents interfere with and impede further research development, exceptions can be made for the granting of exclusive rights to the patent holder if these exceptions relate to scientific experiments derived from the invention. For example, scientific experiments on genetic material samples that were deposited together with the patent application. A case in point at international level is the network of International Agricultural Research Centers (IARCs), which is supported by the Consultative Group on International Agricultural Research (CGIAR) that 
together hold the world's largest ex-situ collection of plant genetic resources. These resources are considered as an international public good and hence they are made available to researchers in every part of the world and all adhere to the restriction that no intellectual property right protection may be sought on material received from the IARCs.

One tool used to encourage access to research is the authorization to use a patent without the patent holder's own authorization (compulsory licences). Compulsory licenses are permitted by the TRIPS agreement in cases where it is in the public interest, if the invention isn't being used sufficiently, or if the patent holder applies anticompetitive practices that hinder access. They also stimulate research aimed at conserving and protecting the environment.

The creation of patent pools has been suggested as a way of overcoming the problem of excessive transaction costs deriving from research activity and from protection of intellectual property. These are institutions that coordinate the exchange of patents for complementary and related innovations, deal with controversies, and exchange information useful for further research (Colangelo, 2004).

The effects of limitations on research from patenting biotechnological innovations can be particularly damaging for developing countries, because of their lack of scientific, technological and entrepreneurial capabilities and their inadequate financial means.

The Biodiversity Convention encourages each nation to develop scientific research on genetic resources provided by developing countries with their full participation (art.15), favoring access to the technologies that use these resources, including those protected by patents and other intellectual property rights (art.16) and the creation of structures and mechanisms to develop research in the countries where genetic resources are located (art.9). The Convention also requires that developed nations put financial resources 
at the disposal of developing countries so that they can fully sustain the necessary additional costs, based on a common agreement (art.20).

The 2001 FAO International Treaty on Plant Genetic Resources introduces a Multilateral System in order to facilitate access to genetic resources (art.10) without cost, or at a minimum cost, in particular for purposes of research (art.12). Access to information should always be allowed and those who have benefited from it should not be granted intellectual property rights or other rights that could limit the further diffusion of resources.

\section{Intellectual property rights on biotechnology and excessive market} power.

The second consequence of assigning excessive exclusion power to a patent holder is the possibly excessive market power enjoyed when the biotechnological innovation is marketed. This becomes a problem when the innovation is recognized as socially beneficial, so that it is in society's interest that the innovation is quickly diffused. The conflict derives from the objective need for a low price, while the patent keeps it at too high a level. A problem of equity can arise, as in the case of new drugs considered essential to cure serious and widespread illnesses, when those who require them do not have the income to afford the expenditures imposed by the high price resulting from the protection of intellectual property.

The problem does not only occur with biotechnological innovations. One way to deal with it could be to act selectively regarding the duration of the patent. This is not a particularly advisable solution, as in setting the optimal duration of a patent, current consumers' welfare losses from monopolistic pricing should be compared to future benefits for consumers deriving from the stream of innovation stimulated by the patent, and these future benefits are extremely difficult to quantify. 
The most advisable way to address this problem is healthy competition in research activity for inventions. It is true that the patent imposes entry barriers, but it is also true that this stimulates the drive to innovate which overcomes these entry barriers through the development of new products and techniques to be patented. This is a typical application of the so called "Schumpeterian destructive creation" process, when the new inventor is able to crowd out the old one (Aghion and Howitt, 1998). What should be noted is that there is a relationship between reducing exclusion power from research and reducing monopolistic power. It also emerges that procedural rules that ensure patentability of new techniques to produce an existing product as well as of new products obtained by the same technique, are not only as a means to reduce excessive exclusion power from research, but also excessive market power associated with the patent.

To better understand this point, consider the example of the so-called GURTs (Genetic Use Restriction Technologies) whose most recent version, known as "terminator technology" renders harvested seeds sterile and obliges farmers to re-buy the seeds from the producer of the genetic innovation (Swanson, 2002). The "terminator technology" has been jointly developed by the US Department of Agriculture and a major American cotton seed producing company (Delta and Pine Land), and the patent was jointly granted to both. The effect was quite simply to increase the value of seed owned by the US company and to open new markets, especially in developing countries (Dutfield, 2004, p.77). It has been argued that the excessive market power comes from the fact that farmers are forced to buy their seeds from the same producer. But this is not the true reason. The power derives from the monopolistic position of the seeds' producer. With alternative "terminator technologies" available, farmers would have a choice, and the market power would be reduced. Within an appropriate regulatory framework, patents could provide the incentive for further research and achieve more competitiveness. 
To address the problem of equity, society should perhaps decide to incur at least part of the cost that consumers of the patented product or final users of patented processes pay as the patent's rent, thus allowing those who need the patented product or process to buy it at a price they can afford. This can be obtained at a national level by means of a redistributive fiscal policy, and at an international level by means of conditional transfers from rich to poor countries.

In biotechnologies, there are examples of market power that can be explicitly addressed with antitrust measures rather than with measures acting on patent procedures. Here is an often cited case. Montsanto had made huge profits from its own patented herbicide Roundup. Concerned with the shortfalls of profits following the patent's expiration, Montansto developed and patented GM seeds containing a gene resistant to Roundup. However, the company contractually obliged farmers to buy these Roundup Ready seeds together with the patented herbicide. Montsanto denied that its objective was to increase the use of herbicides, but conceded that its main interest was to ensure that farmers continued to use its own herbicides (Dutfield, 2004, p.63). This case typically reveals the existence of a market power problem linked to protection of intellectual property granted by the patent that should be dealt with by antitrust authorities rather than by patent procedures or by patent awarding authorities.

\section{Patenting biotechnologies and the distribution of benefits to developing countries.}

Developing countries claim that the distribution of benefits from commercializing patented innovations obtained in developed countries ignores the role of many developing countries as suppliers of genetic resources (the raw materials) for biotechnological innovations. They 
demand that this role be recognized by redistributing at least a part of the innovation rents to them.

They also accuse the present patent system of being organized in such a way that returns are only recognized to the final innovation phase, i.e. for companies in developed countries. What they demand is that protection mechanisms for property rights be revised so as to explicitly recognize the role of the initial phase of the entire biotechnological innovation process, which involves the supply of primary genetic resources and biodiversity, and the contribution of the traditional knowledge of indigenous communities and local farmers.

Developing countries also claim that property rights over genetic resources are implicitly assigned to those who have an interest in exploiting them, and the related biodiversity. Yet this is not necessarily the case. A developing country will not necessarily use the shared rent to conserve genetic resources and biodiversity, as experience shows.

A more convincing argument is that, if the contribution of traditional knowledge in developing countries to the innovations is not recognized, this discourages the use and preservation of traditional knowledge, thus depriving the human community of the opportunity to make full use of the ability to decipher the informational content of biodiversity which the indigenous communities and local farmers possess. (Dutfield, 2004, pp.54$55)$.

Another convincing argument is that when protection through patents turns the farmers in developing countries into providers of free raw materials, making them totally dependant on suppliers from industrialized countries for basic inputs such as seeds, this reduces their function as potential innovators who use local genetic resources. (Shiva, 2001). 
The positions of developing countries are recognized in international treaties. The preamble of the Biodiversity Convention affirms that states have sovereign rights on their own biological resources. Yet this is not an absolute right as the preamble itself acknowledges, specifying that the conservation of biological diversity is a common concern of humankind and that states are responsible for conserving their biological diversity and for using their biological resources in a sustainable manner.

Art.15 and 19 of the Biodiversity Convention require that the results of research and the benefits arising from the commercial utilization of genetic resources should be shared in a fair and equitable way, especially with the developing countries holding the genetic resources used in the innovation process.

The role of traditional knowledge is recognized by the Biodiversity Convention, which states that each country should respect and maintain the knowledge, innovations and habits of local indigenous communities, whose traditional lifestyles are important for the safeguarding and sustainable use of biodiversity (art.8).

The FAO International Treaty on Plant Genetic Resources explicitly recognizes the contribution by the local and indigenous communities and farmers, in particular those living where crop diversity originates from, to the conservation and development of genetic resources (art.9). National governments should take steps to protect and promote the rights of farmers, including the protection of their traditional knowledge and the right to participate at an equal level in the benefits derived from the use of genetic resources.

The FAO International Treaty on Plant Genetic Resources also considers the above mentioned multilateral system as an instrument whose function it is to distribute in a fair way the benefits arising from the utilization of genetic 
resources (art.10). Those who commercialize genetic material received from the multilateral system must pay a sum to be defined by the system's governing body as a fair share of the benefits from commercialization (art.13).

Problems arise because it is often difficult to find any objective criteria to establish how benefits should be apportioned to the countries concerned. As an example, consider the following case. Big profits have been obtained by Eli Lilly from two anti-cancer products derived from a plant (Catharanthus Roseus) originally found in Madagascar, but existing throughout the tropics for long enough to be considered a native plant. Moreover, the ethnobiological knowledge which attracted Eli Lilly and University of Western Ontario researchers came not from Madagascar but from rural communities in the Philippines and Jamaica (Dutfield, 2004, p.47). Should benefits be assigned only to Madascagar? What criteria should be used in distributing and sharing benefits among different countries?

The case just mentioned can be considered a typical example of a phenomenon known as "biopiracy”, referring to the fact that many patents have been granted for products deriving from genetic resources coming from developing countries, without the consent of the owners of the resources, or even without informing them (Martinez Alier, 2002).

The former example also shows how difficult it is to establish primary ownership of the genetic resource or of related traditional knowledge.

However this is sometimes possible, and in these cases the discovery of an example of biopiracy can be used to unmask the non-novelty of an innovation. There have been cases where the patent was revoked on the grounds that traditional knowledge already existed on the property of the patented innovation (Dutfield, 2004, p.50 e p.53). 
Difficulties can be encountered within a country in distributing the commercial benefits of a patent to individual persons on the basis of their role in utilizing traditional knowledge, as such knowledge is normally considered common heritage of public domain to which everybody has free access. This argument is also used against the use of traditional knowledge as a factor determining the distribution of the benefits of patent commercialization. The argument goes as follows: if traditional knowledge is public domain within the borders of a country, there is no reason why the same should not apply outside the country's borders (Stenson and Gray, 1997). However, this argument ignores the fact that traditional knowledge fell into public domain owing to abuses of human rights towards indigenous people who were denied and deprived of individual rights to their knowledge without any prior consent (Dutfield, 2004, p.58).

The fact that the right of developing countries to share the benefits of biotechnological innovation is acknowledged in international agreements is important, but it is only a necessary condition for enforcing such a right. Reforms are first of all required in intellectual property laws and in the regulatory systems of developed countries.

Many negative effects of patents in terms of excessive exploitation of traditional knowledge could be avoided by introducing more rigorous procedures to screen patent applications into the intellectual property laws of advanced countries. Any application should be required to explicitly take into account the pre-existing knowledge on which the patentable innovation might be based.

We must always be aware of the strategic aspects which can lead individual countries to delay such reforms because of the fear of losing an advantageous position in the international market. Only a strong awareness of the social benefits of reforms in countries or groups of countries whose key role in biotechnology is internationally acknowledged, can change the 
status quo. Such awareness can be achieved through the pressure of public opinion in individual countries and on a global level.

\section{Conclusions}

Biotechnology is a sector of technological progress destined to become ever more important for the future of mankind. However, it is a new technology whose uncertain future effects can have a positive or negative sign, depending on the type of innovation considered.

The uncertainties of the degree and timing of social costs and benefits deriving from biotechnological innovations require particular attention to be given to the use of traditional tools for providing incentives for these innovations, and in particular the protection of intellectual property, for example patents for new inventions. Blocking patentability tout court is not an appropriate solution and may indeed be counterproductive. It is preferable to act on reforming patenting procedures. It is very important to consider that granting a patent does not automatically grant authorization to use the patented invention; and that in any case, the procedure for obtaining a patent guarantees an element of transparency. However, it cannot be denied that a patent as such tends to promote the innovation and is therefore a tool which, by its very nature, highlights the benefits rather than the costs of the innovation itself. The most expedient approach is to perfect the patenting procedures as much as possible, and to accompany them with provisions for legal liability and with a better functioning of antitrust rules.

In international treaties and in particular in the Biodiversity Convention, the focus is on the need to discourage biopiracy and to encourage developing countries that own the genetic resources to participate in research and share the benefits of biotechnological innovations, both in terms of participating in returns from the innovation allowed by the intellectual property rights and in terms of the use of the innovation itself for the purpose of their 
development. This is no easy task. Developed countries should feel responsible for the enforcement of the principles enshrined in international treaties by adjusting their own legislation on intellectual property rights and on antitrust, so as to prevent protection of property rights from leading to an underestimation of the social costs of innovations and to excessive exclusion rights and market power.

\section{References.}

P.Aghion, P.Howitt, Endogenous Growth Theory, MIT Press, Cambridge, Mass., 1998.

C.M Correa, Intellectual Property Rights, the WTO and Developing Countries, Zed Books, New York, 2000.

G.Colangelo, L'antitrust, i patent pools e le tragedie della intellectual property governance, in Mercato, Concorrenza e Regole, Il Mulino, Bologna, aprile 2004, pp. 54-73.

V. Di Cataldo, Biotecnologie e diritto. Verso un nuovo diritto e verso un nuovo diritto dei brevetti, Contratto e impresa, CEDAM, Padova, 2003, pp.319-394.

G. Dutfield, Intellectual Property, Biogenetic Resources and Traditional Knowledge, Earthscan, London, 2004.

T.Goeschl, T.Swanson, The Social Value of Biodiversity for $R \& D$, Environmental and Resource Economics, 22, 2002, pp.477-504.

T.Goeschl, T.Swanson, On Biology and Technology: The Economics of Managing Biotechnologies, Fondazione ENI Enrico Mattei, Nota di lavoro 42.2003, Milano, 2003. 
T.Goeschl, T.Swanson, Managing the Pace of Technological Change: the Case of GMOs, paper presented at the Bioecon Workshop, Cambridge, UK, 2004.

M.A.Heller, The Tragedy of Anti-Commons: Property in the Transition from Marx to Markets, Harvard Law Review, 1998.

W.Landes, R.Posner, The Economic Structure of Intellectual Property Law, Harvard University press, Cambridge Mass., 2003.

J.Martinez-Alier, The Environmentalism of the Poor, Edward Elgar, Chelteham UK, 2002.

K.Maskus, Intellectual Property Rights in the Global Economy, Institute for International Economics, Washington D.C., 2000.

V.Shiva, Campi di battaglia: biodiversità e agricoltura industriale, Edizioni Ambiente, Milano, 2001.

A.Stenson, T.Gray, Cultural Communities and Intellectual Property Rights in Plant Genetic Resources, in T.Hayward, J.O’Neill (a cura di), Justice, Property and the Environment, Ashgate, Aldersht and Brookfield, 1997, pp.178-193.

T.Swanson, Global Action for Biodiversity, Earthscan, London, 1997.

T.Swanson, Biotechnology, Agriculture and the Developing World, Edward Elgar, Chelteham UK, 2002. 